\title{
FEATURES OF SOCIAL AND EDUCATIONAL SUPPORT OF YOUNG PARENTS AND THEIR CHILDREN
}

\author{
HALYNA MYKHAILYSHYN, OLENA BUDNYK
}

\begin{abstract}
The article presents social and educational aspects of early (teenage) pregnancy, young motherhood. The authors grounded negative consequences of early pregnancy and the peculiarities of social and educational support for young parents and their children. The authors described experience Centre for Teen Parents: moral and psychological preparation of pregnant teenagers to deliver the baby, directions and methods of working with young families, especially setting up comfortable psychological interaction using innovative methods of working with preschool children, providing conditions for young mothers to continue education in schools, counseling young families on resolving housing issues, financial support and others.

The paper emphasizes the need for preventive work to keep teenagers from pregnancy, carrying out social and educational events in terms of promoting healthy and responsible parenthood and others.
\end{abstract}

Keywords: social and pedagogical work, early motherhood, teen pregnancy, children of preschool age, young family, Centre for Teen Parents.

\section{INTRODUCTION}

Current trends of globalization, accelerated urbanization, dominance of outdated gender stereotypes, increased poverty, acceleration, easing contacts in the "parent-child" chain caused the problem of early motherhood.

The essence of the young motherhood means carrying, birth, child care and education of mothers of young children (under 21). It has its own socio-cultural and economic reasons and risks for health and social formation of the young mother and her baby. Today, according to research, the number of teenage abortions in the world is 4.2 million cases per year; 15 million babies birth by teenage mothers, about 60 thousand. Women die each year during childbirth or abortion. This sad statistic demonstrates the urgency of adolescent motherhood [2, p. 3].

For example, in Republic of Ireland (ROI) 14\% of all registered births were mothers under the age of 25 (2008). In Northern Ireland (NI) 5\% of the registered births were mothers under 20 (2010). Almost $80 \%$ of these births in the Republic of Ireland and $97.5 \%$ in Northern Ireland were outside marriage; either to soloparents or co-habiting couples. This is compared to $33 \%$ of births outside marriage for all age groups [14]. 
Teenage parenthood is one of the challenges that can have a considerable impact on a young person's life and is associated with a number of adversities. For example, it is more likely to occur with young people from a low socio-economic background, who are under-achieving in their education, who misuse drugs and/or alcohol, or who are engaged in antisocial behavior [13].

Early (teen) pregnancy, in most cases leads to a number of phenomena: teenage mothers usually leave school (about $25 \%$ of them did not continue their education); these mothers are more likely than their peers have problems with employment; stress obtained by early (sometimes unwanted) motherhood adversely affect the education of the child and others.

For young women, coping with a disadvantaged background is hard enough. Having a baby during adolescence only makes matters worse. Compared to women of similar socio-economic status who postpone childbearing, teen mothers are more likely to end up on public assistance. Teen mothers are less likely to complete the education necessary to qualify for a well-paying job - only $41 \%$ of mothers who have a child before age 18 ever complete high school [12, p. 4].

Not by chance the problem of young motherhood and preventive work to prevent early pregnancy is covered in the scientific works of scientists: I. Bratus, I. Emmerová, L. Horwood, D. Fergusson, K. Moore, P. Morlins, L. Ponon, R. Price-Robertson, T. Tyureman, P. Trades, S. Hatcher, L. Woodward and others. Current trends of globalization, rapid urbanization, dominance of outdated gender stereotypes, increase of poverty, acceleration, easing contacts in the "parent-child" system caused the problem of early motherhood.

Moreover, stress obtained by early (sometimes unwanted) motherhood adversely affects the education of the child and others. Therefore, problems of early motherhood and instructive work to prevent early pregnancy are covered in the scientific heritage of many scientists.

In many countries (the UK, the USA, Finland, etc.) socio-pedagogical and psychological help to young mothers is realized on the macro (development of social and educational strategies to implement appropriate programs at the national level), medium (implementation of socio-pedagogical support at the level of local communities, including centers for underage mothers and their children) and micro (individual socio-psychological and pedagogical work with teenage mother) levels.

Unfortunately, society is not ready to accept properly a teenage mother because of the numerous stereotypes. "Isolation is a common problem experienced by young parents as it can be difficult to maintain former relationships with friends due to a lack of opportunities to socialize with them. They can feel they have become 'out of touch' with their friends' concerns or interests. Isolation can have devastating effects on both the child and the parent and confidence levels can drop very quickly. Youth workers need to be aware of what options young parents have in accessing services which will help them when they feel isolated. They can play a vital role in supporting young parents to continue to engage with youth groups/programs. For example, young parents can be encouraged to access general programs such as drama, young women's groups, community-based youth activities or more specialized programs like Teen Parent Support Programs. Added to the emotional challenges often associated with solo-parenting and the lack of public acceptance of one-parent families, life on a low income can make stress levels particularly high" [14].

Often there is the phenomenon of social exclusion, discrimination, lack of understanding and willingness to help. Besides, i.e., the TV show "Pregnant at 16 " is in some way intended to explain to young people what a young girl feels, which difficulties she may have when she gives a birth to a child at an early age. Often she has no understanding among peers, parents, boys, etc. Thus these children either are given up for adoption or are aborted.

Therefore the researchers actualized problem of providing social, educational and psychological support for young mothers and young families who are at risk. Indeed, through condemnation in society they can harm the health or life of a newborn child. There is also a high risk of rejection of the child.

This article describes the work experience of the Centres for Teen Parents, in particular, moral and psychological preparation of pregnant teenagers to deliver a baby, directions and methods of working 
with young families, especially social and psychological counseling, using of the innovative methods of working with preschool children and others.

\section{ANALYSIS AND DisCUSSION}

\subsection{SOCIAL AND EDUCATIONAL WORK AT THE LEVEl OF LOCAL COMMUNITIES}

Young parents differ in national or socio-cultural characteristics, but they share common problems dealing with birth and upbringing of the child, continuing education, establishing social contacts, etc. The creation of such centers for young parents in many countries of the world with such specialists as teachers, psychologists, managers, doctors and others is becoming a common practice. To start this deal, the center staff carefully studies the problems and desires of pregnant girls or young families and jointly determines areas of the appropriate support. For example, if the family requires child care, they will be directed to the Child and Family Support Centre, an on-site accredited childcare centre. If the young mom's looking to complete high school, she will be directed to the Educational Support Service workers, and the School administration.

Ivan Bratus determines social and psychological characteristics of young mothers: conflicting relationships with parents; poor education level; poverty; legal insecurity; early sexual activity; addictive behavior; immature emotional and volitional spheres; anxiety, unformed maternal affection; infantilism; focus on seniors; help; low self-esteem; emotional instability; social alienation; complex of victims of sexual violence; indifference to own health and the health of the child [2].

Therefore young family feels considerable difficulties after the baby is born.

Many teen mothers just need extra support to finish school, find full-time work, go to college, amend relationships with their parents and become better parents themselves. Before the sexual revolution, the stigma of teen pregnancy had less to do with the baby and more to do with being unwed. The overwhelming majority of those mothers gave their babies up for adoption [7].

In this difficult life period such centres encourage young families to group activities, including young future moms and dads who can ask questions on the topic. An important issue is personal awareness of the childbirth and care for it. However, the center organizes monthly trips for these teens to share tips and get the experience of social interaction in the group. In the family atmosphere of fun future young parents can discuss with each other their new responsibilities.

The centers employ specialists who can also offer expert psychological help to future young parents in recovery contacts with the family. In particular, advisory services, concerning the problem how teenagers should tell their parents about pregnancy, how to maintain warm relations and accept sometimes perceived abuse of social media and more.

Among the problems young families face are low income, difficulties in completing high school, learning disabilities, alcohol and substance abuse, family violence, social stigma, and mental health issues. These centres run many valuable programs designed to solve these issues.

Young fathers also need support around the following issues: values and attitudes in relation to relationships and parenting; taking responsibility; communication skills; decision-making; coping with discrimination; building a child's self-esteem; helping children learn; dealing with conflict and accessing available supports, etc.

Another interesting program is the Young Dad's Outreach program, where young dads can attend some sport and recreational events, play with their children and meet other dads and share their experiences, problems and solutions. The interesting fact is that all "parenting skills training" and "young dads coaching" programs happen in a very organic way, by chatting with facilitators during rides from events, through casual conversations with other dads and events' organizers while engaged in the activities.

Tremendous support to young parents is given at the Child and Family Support Centre. Babies can be accepted here from three weeks old until they are three years old. Young moms are encouraged to visit their babies as much as they can and they indeed tend to spend a lot of time in the playrooms. It's a perfect time for early childhood educators to review baby care practices and teach young moms child 
care skills. Sometimes they model positive interactions; sometimes they have a meaningful conversation with a mom regarding preparing formula or dealing with the baby's diaper rash. Sometimes, they simply listening young moms concerns and gently offer encouragement and assess her resources.

Modern young even quite successful families often come across situations where mothers are constantly tired to deal with a child who is often too naughty. Moreover, they have no experience of such care. And despite their very young age (sometimes 15-16-year-old mothers refer to the center of), so most parents still want to have fun of their private life and just relax. They have mentally not yet ready for family life and child upbringing. Accordingly, the positive aspect is that that time when young moms or dads participate in cultural or entertaining program or are enrolled in school, their children are under the supervision of specialists, as the center has well-organized proper nutrition and psychological support, social and educational support and more.

As the experience of the Nordic countries shows (Sweden, Finland), a fairly common and effective form of social and educational support to early mothers is the work of relevant psychological centers to relieve stress, which is typical during the teenage pregnancy forming an objective assessment of the causes of the crisis, the search for optimal ways out of the situation and others. It is important that these assistance centers exist on mostly confidential basis where young people can trust and feel safe.

The Australian Young Pregnant and Parenting Network (AYPPN) has been recently established to "connect all those working to improve outcomes for pregnant and parenting young people and their children, and to advocate for better policy and program support" [11, p. 7].

Designing an appropriate social and educational environment is the organizational and methodological basis for effective implementation of inclusive education. Let us determine the following components that form this environment [1, p. 73-74]: socio-psychological (taking into account individual psychological development and behavior specific to a person in a process of social interaction, promoting ethical and moral standards in socialization and communication, adequate attitude to positive or negative traits in the behavior of others, pedagogical aiming at correcting deviations, forming habits of tolerant interaction, etc.); informational (availability of up-to-date regulatory and educational support of the inclusive process); cultural and educational (pedagogical competence of participants of the educational process that encompasses content, forms, methods, tools, innovative technologies, etc.); logistical (availability of modern multimedia, audio and video facilities, adaptation of school's physical environment, taking into account elements of aesthetics in the interior, etc.).

\subsection{Social and Educational Assistance to Young Parents and their Children in TERRA CENTRE}

In order to provide social, educational and psychological support to pregnant teenagers, young families (mostly underage parents) and their children in Canada (Edmonton, Alberta) Terra Centre for Teen Parents is successfully operated.

Terra began in 1971 as a small group of young moms who wanted more for themselves and their children. They were determined to complete their high school education striving for a more promising future. This was the first step towards shaping Terra's pregnancy centre as it is today. In these early years the mission was entirely focused on high school completion and providing counselling services while encouraging young moms to support each other. In 1974, the name of the organization was changed into Terra - Meeting the Challenge of Teen Pregnancy. At about that time, approximately 100 young moms in were being served and more teachers and social work staff were needed. New funding from United Way and Health Canada (Public Health Agency of Canada) brought new opportunities to grow and meet more needs of young parents. In Canada the Center began to enjoy considerable popularity. More and more young parents need qualified psychological and pedagogical support in parenting and personal realization in the society. Thus there appeared the question of creating Terra's Child and Family Support Centre in its earlier years. In 1998, the Child and Family Support Centre 
opened onsite at Braemar School accommodating 54 infant and toddlers and offering additional support services for students [9].

Currently, the task of the center is to help young parents not only to care for their children from an early age. It is important to help young mothers especially adolescent obtaining secondary education, and develop in spiritual, artistic or sporting field. Therefore the Centre is now the organization that offers a multifaceted, comprehensive approach to help young parents and their children reach their full potential. A team of different specialists of Terra Centre pays considerable attention to the issue of establishing social and educational interaction with gifted children and children with disabilities (with special needs) $[1 ; 3]$.

The Centre receives under-aged parents who did not find support in their own families or community. Usually they live in poverty, most of them cannot afford themselves even to purchase high-quality food products for themselves and children, clothes, diapers, rent apartment and others. Therefore, center employees work to raise funds to help people who need it. It is very important that young families become more confident, educated and eventually achieved their goals in life [10]. Donations are distributed in the center in the absolutely fair form, as every young family has an equal chance to succeed and does not use special patronized care by the staff. Primarily donations are directed to most needy people. Social and educational assistance is based on the individual characteristics of the young mother.

The Terra Child and Family Support Centre is also a pilot site for "Play, Participation, and Possibilities: An Early Learning and Child Care Curriculum Framework for Alberta" [5]. It is a guide for early childhood educators to use in their everyday work with young children and their families in Alberta. It builds on early learning and child care frameworks that have been developed in other parts of Canada and around the world, in particular the New Brunswick framework for early learning and child care.

Play, participation, and possibilities mean focus on features of early child education, taking into account its strengths in the development of personal values. Center specialists work according to the Italian method of Reggio Emilia [6]. At the same time they teach young parents that it is necessary with your child sing, including listening to music, develop sensory perception to give normal development to the child. They also teach to remember the need strengthening physical health, including daily exercise, massage, outdoor walks, etc.

For example, in Finland there are similar centers as in Canada, they help young (juvenile) mothers, parents with mental health problems and immigrants. Caregivers who work in these centers, accompany the young mother during childbirth and provide advice in the first weeks (months) after birth. If a young mother studies at school, a child is taken care of by the teacher. Importantly, when it turns out that the young mother cannot properly look after her child, then social workers can give this child to another family for a while maintaining parental rights (native parents have the right to periodically visit the child and optionally within some time take it back).

\section{CONCLUSIONS}

The problems of teenage pregnancy, early motherhood and parenting in young families are important for many countries. After all, negative consequences of early pregnancy and motherhood are poverty, economic failure of girls independently ensure the quality life for themselves and their child, social isolation, limited opportunity for education (profession), psychological problems, the risk of disease and discrimination in society, health or life risks of the child.

Social and education assistance to young parents and their children in many developed countries (Canada, the USA, the UK, Germany, Sweden, etc.) includes:

1) recognition of the challenges of young mothers and pregnant teenagers;

2) establishment of national councils with representatives of civil community organizations that aim to develop the issue to overcome problems and to monitor implementation of the tasks; 
3) certain social services (shelters for young mothers and their children), that are interdisciplinary team of experts (teachers, psychologists, social workers, doctors, lawyers);

4) foster and assist families who sometimes take custody of the young mother and her child;

5) organization of special training (short courses) to prepare pregnant teenagers to deliver the baby, formation life skills of partners;

6) carrying out preventive work in terms of early pregnancy and motherhood among adolescents and young people.

We believe that the experience of the developed countries in providing psychological, social and educational assistance to young parents and their children is extremely useful for Western and Eastern Europe. These questions are extremely relevant today for all the post-Soviet countries, in which still there is a significant part of juveniles who need such support. Indeed, in many countries, i.e., Ukraine, organizations are set up, which help young parents, mostly single mothers get financial donations from organizations and individuals on the basis of volunteering. Often this is done haphazardly and situationally, there is no strategic program of social and educational support. Due to lack of funding there are difficulties in social work with groups.

The following examples show us perspectives to consider the arrangement of a network of centers to help mothers and children, creation of conditions for continuing their education, organizing training programs for pregnant teens to prepare them for childbirth and responsible parenthood, encouraging socio-educational events in promoting healthy parenting and more.

\section{REFERENCES}

[1] Budnyk O. Inclusive education. Publisher Boichuk A.B., Ivano-Frankivsk, 2015. (in Ukrainian)

[2] Bratus I.V. Social and educational work with young mothers in the US and UK. Dissertation for the degree of candidate of pedagogical sciences, specialty 13.00.05 "Social Pedagogics". Lugansk, 2007. (in Ukrainian)

[3] Dubkovetska I., Budnyk O., Sydoriv S. Implementing inclusive education in Ukraine: problems and perspectives. Journal of Vasyl Stefanyk Precarpathian National University. Scientific Edition: Series of Social and Human Sciences, 3 (2-3) (2016), 99-105. doi:10.15330/jpnu.3.2-3.99-105

[4] Emmerová I. School preventive socio-educational work of social pedagogues in the Slovak republic and an outline of their activities in the other V4 countries. The New Educational Review, 46 (4) (2016), 95-103. doi: 10.15804/tner.2016.46.4.08

[5] Makovichuk L., Hewes J., Lirette P., Thomas N. Play, participation, and possibilities: an early learning and child care curriculum framework for Alberta. Available at: www.childcareframework.com.

[6] Pedagogy of Reggio Emilia. Available at: http://goroddetstva.ru/parents/prog/pedagogika-redzhioemilii.html.

[7] Perception clashes with reality for Edmonton's teen moms. Available at: https:/terracentre.ca/wpcontent/uploads/2015/09/2013_Perception_-Metro.pdf.

[8] Yuen Francis K.O. Teenage pregnancy and parenthood: Global perspectives, issues and interventions. In: Holgate H., Evans R. Routledge, New York, 2006.

[9] Terra Centre. Available at: https://terracentre.ca/what-is-terra/.

[10] Organization helping young mothers runs out of diapers, needs donations. Available at: https://terracentre.ca/wp-content/uploads/2015/09/2013_05_28_diaperhelp_-CTV-Edmonton.pdf.

[11] Rhys Price-Robertson. Supporting young parents. CAFCA Practice Sheet, November (2010). Available at: https://aifs.gov.au/cfca/sites/default/files/publication-documents/ps3.pdf.

[12] Teenage births: Outcomes for young parents and their children. Schuyler Center for Analysis and Advocacy, NY, 2008. Available at: http://www.scaany.org/documents/teen_pregnancy_dec08.pdf.

[13] Woodward L.J., Horwood L.J., Fergusson D.M. Teenage pregnancy: Cause for concern. New Zealand Medical Journal, 114 (1135) (2001), 301-303. 
[14] Working with young parents. Available at: http://www.youth.ie/sites/youth.ie/files/Chapter\%209\%20\%20working\%20with\%20young\%20parents\%20-\%20all\%20Ireland_1.pdf.

Address: Halyna Mykhailyshyn, Olena Budnyk, Vasyl Stefanyk Precarpathian National University, 57, Shevchenko Str., Ivano-Frankivsk, 76018, Ukraine.

E-mail: galmuh60@gmail.com, olena.budnyk@pu.if.ua.

Received: 30.11.2017; revised: 12.03.2018.

Михайлишин Галина, Будник Олена. Особливості соціально-педагогічного супроводу юних батьків та їхніх дітей. Журнал Прикарпатського університету імені Василя Стефаника, 5 (1) (2018), 107-113.

У статті представлено соціально-педагогічні аспекти проблеми ранньої (підліткової) вагітності, юного материнства. Обгрунтовано негативні наслідки ранньої вагітності та висвітлено особливості соціально-педагогічної підтримки юних батьків та їхніх дітей. Автором описано досвід роботи Центру для молодих батьків: морально-психологічна підготовка вагітних підлітків до пологів, напрями та методи роботи з мододою сім'єю, особливості налагодження комфортної психодогічної взаємодії, використання інноваційних методик роботи з дітьми дошкільного віку, забезпечення умов для продовження мододими матерями навчання в школі, консудьтування мододої сім'ї щодо вирішення житдових питань, фінансова підтримка та ін.

Наголошено на потребі превентивної роботи щодо запобігання піддіткової вагітності, проведенні соціально-педагогічних рекламних акцій щодо популяризації здорового і відповідального батьківства та ін.

Ключові слова: соціально-педагогічна робота, ранне материнство, підліткова вагітність, діти дошкільного віку, молода сім'я, Центр дия юних батьків. 